\title{
Research Article \\ Assessment of pesticide use in major vegetables from farmers' perception and knowledge in Dhading district, Nepal
}

\author{
Sandesh Bhandari ${ }^{1 *}$, Sushma Paneru ${ }^{1}$, Shailesh Pandit ${ }^{1}$, Sramika Rijal ${ }^{2}$, \\ Hira Kaji Manandhar ${ }^{3}$ and Bishnu Prasad Ghimire ${ }^{4}$ \\ ${ }^{1}$ Faculty of Agriculture, Agriculture and Forestry University, Rampur, Chitwan, Nepal \\ ${ }^{2}$ Department of Agri-botany and Conservational Ecology, Agriculture and Forestry University, \\ Rampur, Chitwan, Nepal \\ ${ }^{3}$ Department of Plant Pathology, Agriculture and Forestry University, Rampur, Chitwan, Nepal \\ ${ }^{4}$ Under Secretary, Ministry of Agriculture and Livestock Development, Nepal \\ Correspondence: bhandarisandesh2000@ gmail.com \\ ORCID: https://orcid.org/0000-0001-5364-1192
}

Received: August 12, 2019; Accepted: November 19, 2019; Published: January 7, 2020

@ Copyright: Bhandari et al. (2020).

\section{(c) (1) (\$)} International License .

\begin{abstract}
A field study was carried out to assess the pesticide use status in major vegetable crops from farmers' perception and knowledge in Dhading, Nepal in 2019. Field study was carried with 100 commercial farmer's using semistructure questionnaire by face to face interview. This study was analyzed by categorization of farmers into small holder (51) and large holder (49) groups on the basis of mean area of vegetable cultivation (6.48 ropani). The highest amount of pesticides is needed in tomato in both large holders and small holders according to the farmer's experience. Among the study farmer's, $41 \%$ of them spray the pesticides by making a cocktail or mixed method and 56\% follow the waiting period of 3-5 days in both of the cases. A significant positive correlation was found at $5 \%$ level of significance between the knowledge and practice pattern of waiting period of the pesticides and negative correlation was found between the Personal Protective equipment score and health hazard score. Headache was the major health hazards faced by the farmers which was higher in small holders $(66.7 \%)$ as compared to the large holders $(46.9 \%)$. Mask was the most used PPE by the farmer's i.e. by $83 \%$ in overall. Fourty three percent of the farmer's throw the pesticide containers in secret place after using of it. The use of PPE was seen lower in small holders as compared to the large holders. This study reveals the necessities of suitable program and policies regarding the knowledge, safe handling and use of pesticide among the farmer's level.
\end{abstract}

Keywords: pesticide, vegetable, farmer's, small holders, large holders

Correct citation: Bhandari, S., Paneru, S.,Pandit, S., Rijal, S., Manandhar, H. K., \& Ghimire, B. P. (2020). Assessment of pesticide use in major vegetables from farmers' perception and knowledge in Dhading district, Nepal. Journal of Agriculture and Natural Resources, 3(1), 265-281. DOI: https://doi.org/10.3126/janr.v3i1.27180 
Journal of Agriculture and Natural Resources (2020) 3(1): 265-281

ISSN: 2661-6270 (Print), ISSN: 2661-6289 (Online)

DOI: https://doi.org/10.3126/janr.v3i1.27180

\section{INTRODUCTION}

Agriculture contributes 33\% of total Gross Domestic Product (GDP) and 54\% of the total population are engaged in it (ADS, 2016; NPC, 2016). Worldwide loss in agricultural crops due to pest infestation is more than 45\% (Abhilash \& Singh, 2009). The total yield loss of crop plants from insect pests and diseases ranges from 25-35\% in Nepal (PPD, 2012). Farmer's generally use chemical pesticides due to its easy availability, quick response and preference of consumer's to visually appealing products. These pesticides are the substances or mixture of substances deliberated for preventing, eradicating, repelling or minimizing the damage of any pest (Eldridge, 2008). Different chemical compounds like insecticides, fungicides, nematicides, herbicides, molluscicides and rodenticides are considered as pesticides. Pesticides are classified as highly or extremely and highly hazardous by WHO and FAO also banned by some countries and unrelenting used in developing countries (WHO, 2003). Globally, two million tons of pesticides was consumed among which $45 \%$ was consumed in Europe, $25 \%$ was consumed in USA and 25\% in the rest part of the world (Abhilash \& Singh, 2009).The domestic consumption of pesticide in Nepal is very low i.e. $0.412 \mathrm{~kg}$ a.i/ha (Sharma et al., 2012) .

The most used pesticides in Nepal are fungicides. In 2011/2012, more than $48 \%$ of the pesticides are used in the form of fungicides (PRMS, 2012). The trend of the pesticide use in Nepal is increased by 10 to $20 \%$ and this expense is one of the major factors in increasing the cost of fruits and vegetables (Jasmine et al.,2008). More than $90 \%$ of the pesticides imported in the country are used in vegetable farming (Atreya and Sitaula, 2010). Majority of the farmers are not aware about the different types of pesticides, safety precaution, its hazardous level on the health of the consumer and environment (Yassin et al., 2002). Farmer's have also experienced the symptoms of headache, skin irritation, burning sensation, teary eyes, chest pain, weakness and other discomfort due to the effects of pesticides (Atreya et al., 2012). Several studies have linked the exposure of pesticides and the incidence of human chronic diseases effecting nervous system, reproductive system, renal system, reproductive system and cardiovascular system (Mostafalou \& Abdollahi, 2012).

Good management use and proper disposal of agrochemicals is an important health and environmental issues in the developing countries (WHO, 2012). The total exposure to the chemical is the sum of exposure during pesticide storing, mixing, applying and disposing of the chemicals (Antonella et al, 2001). These pesticides are inhaled through different routes via; oral (through the mouth and digestive system), dermal (through the skin), occularly (through eyes) or by inhalation (through the nose and respiratory system). Pesticides have effect on the decline of biodiversity by indirect effect to the non-target organisms. Till now 21 most hazardous pesticides have been banned in Nepal (Krishi Diary, 2019).

Dhading district is one of the major supplier of vegetables in the Kathmandu city. And requirement of pesticides in vegetables is comparatively higher than the other food products (Koirala et al., 2009).This study assesses the pesticides use, status of major pocket area for vegetable cultivation, farmer's practices, their knowledge and perceptions regarding the uses of pesticides in Dhading district. 
Journal of Agriculture and Natural Resources (2020) 3(1): 265-281

ISSN: 2661-6270 (Print), ISSN: 2661-6289 (Online)

DOI: https://doi.org/10.3126/janr.v3i1.27180

\section{METHODOLOGY}

This study was carried out in Dhading district, which is located at the hilly region of Nepal and lies in the northwestern part of Province No. 3. The study area includes Benighat Rorang Rural Municipality, Siddhalekh Rural Municipality and Gajuri Rural Municipality which were the major pocket area of vegetables production in Dhading district (Figure 1).

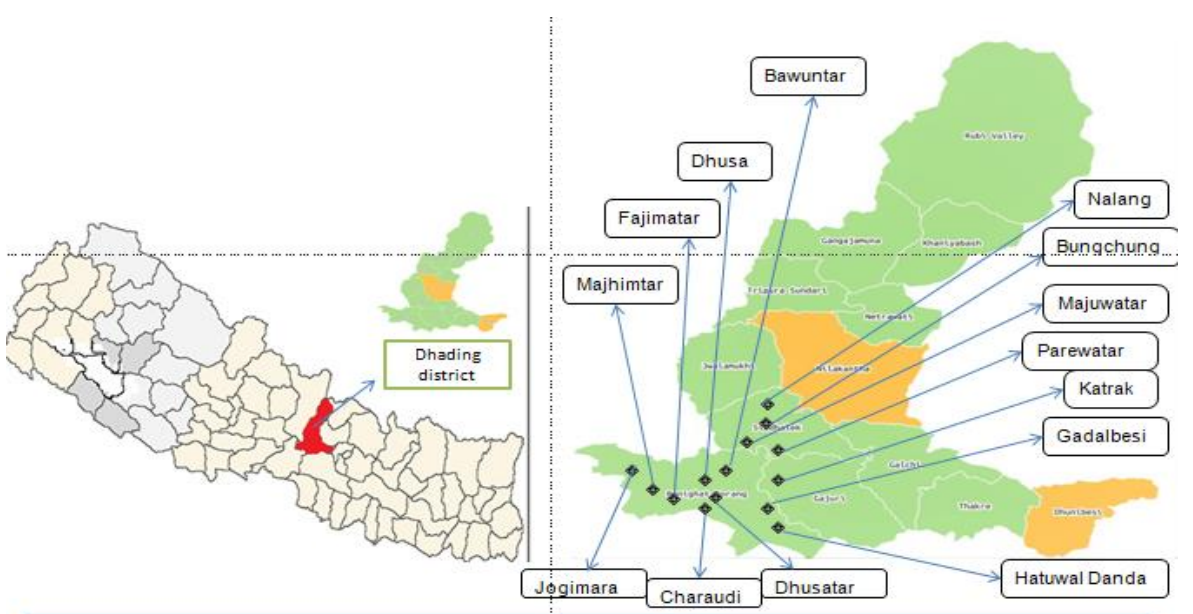

Figure 1: Benighat Rorang, Gajuri and Siddhalekh Rural Municipality (Study area)

A study was conducted with 100 commercial vegetable growers using the semi-structured type of questionnaire considering the purposed of study as well as the availability of resources and time frame of the study. Simple random sampling was used for selecting the sample from the population as it is the most un-biased technique and also provides equal chance to each element for the selection during the study (Scheaffer, Mendenhall, \& Ott, 1987).

Research instruments include Reconnaissance survey, Pre-testing of interview questionnaire, Household interview / Field survey, Pesticide retailer survey, Key informant interview (KII) and Focus group discussion (FGD). Data were obtained from primary sources and secondary sources.

The data were coded, entered and analyzed using Statistical Package for Social Sciences (SPSS) v24 and MS-excel. The mean area (6.48 ropani) of landholding for vegetable cultivation was calculated and respondents were categorized into two groups based on their area of landholdings. The farmers cultivating in area less than or equal to 6.48 ropani were classified into small holder farmers $(\mathrm{n}=51)$ and greater than 6.48 ropani are classified as large holder farmers $(n=49)$. Analysis was done by the comparisons of the two categories of farmers. Descriptive statistics was used to describe the socio-economic and demographic characters of the respondents. 
Journal of Agriculture and Natural Resources (2020) 3(1): 265-281

ISSN: 2661-6270 (Print), ISSN: 2661-6289 (Online)

DOI: https://doi.org/10.3126/janr.v3i1.27180

\section{Scaling techniques}

Qualitative data are taken into account for the preparation of index. On the basis of the respondent frequencies, weighted indexes were calculated for ranking of most used forms of the pesticides and major sources of trust to the farmers. The different pesticides which was most used was ranked by 3 point scale ( 3,2 and 1, respectively). Similarly, the major sources of trust to the farmers were ranked by four point scaling techniques $(1,0.75,0.5$ and 0.25 , respectively). The index of importance was computed by using the formula:

I imp $=\sum \frac{\text { Sifi }}{N}$ Where,

I imp $=$ index of importance

$\sum=$ summation

$\mathrm{Si}=i^{\text {th }}$ scale value

$\mathrm{Fi} \quad=$ Frequency of $\mathrm{i}^{\text {th }}$ importance given by the respondents

$\mathrm{N} \quad=$ total number of respondents

Subedi et al. (2019a) used this above formula to identify the constraints associated with the potato production in Terai region of Nepal. This formula was applied by Shrestha and Shrestha (2017) to rank the problems associated with maize seed production. Subedi et al. (2019b) used this technique to explore the problems associated with wheat production.

\section{RESULTS AND DISCUSSIONS}

The socio-demographic characteristics of the study farmers (100) are presented in the table 1. In the study, farmer's were classified into large holders and small holders to study the actual difference in the pesticides related practices, perceptions and number of trainings attained by them. Among the sampled household, $34 \%$ of the households head were literate among which it was higher in large holder (44.9\%) than small holder (23.5\%). The mean own land holding of the farmer is 13.61 ropani which was significantly higher in large holders (16.93 ropani) than small holders (10.43 ropani) at 5\% level of significance. The major vegetable crops grown in the study area are Cucurbitaceous (Spongegourd, Bottlegourd, Cucumber, and Bittergourd), Cole (Cauliflower, Cabbage), Solanaceous (Brinjal, Tomato) and Leguminous (Snap bean). The cropping patterns of the vegetable crops in study area is: Cucurbitaceous followed by Cole which is followed by Solanaceous/Leguminous. Different pesticides use practices, attitude and knowledge was studied on the basis of these major vegetables.

Distribution of sampled households on the basis of age, family size and gender in the study area

For the 100 respondents of large holders (49) and small holders (51), the mean age of household head of the large holder was higher (53.40 years) than of the small holder (50.43 years.). Average size of the family member was 6.53 in the large holder and 6.29 in the small holder. Age above 59 years among large holder $(0.84)$ and small holder $(0.43)$ was found significant at $5 \%$ level of significance. Higher dependency ratio $(0.75)$ was found in the large holder than in the small holder (0.61) (Table 1). 
Journal of Agriculture and Natural Resources (2020) 3(1): 265-281

ISSN: 2661-6270 (Print), ISSN: 2661-6289 (Online)

DOI: https://doi.org/10.3126/janr.v3i1.27180

Table 1: Distribution of sampled households on the basis of age and gender in study area.

\begin{tabular}{|c|c|c|c|c|}
\hline Descriptives & $\begin{array}{l}\text { Overall } \\
(\mathrm{n}=100) \\
\text { mean }(\mathrm{SE})\end{array}$ & $\begin{array}{l}\text { small holder } \\
(\mathrm{n}=51) \\
\text { mean }(\mathrm{SE})\end{array}$ & $\begin{array}{l}\text { large holder } \\
(\mathrm{n}=49) \\
\text { mean }(\mathrm{SE})\end{array}$ & $\begin{array}{l}\text { Test } \\
\text { t-value }\end{array}$ \\
\hline Age of $\mathrm{HH}$ & $51.95(1.15)$ & $50.54(1.53)$ & $53.40(1.71)$ & -1.25 \\
\hline $\begin{array}{l}\text { Number of family } \\
\text { members }\end{array}$ & $6.41(0.22)$ & $6.29(0.340$ & $6.53(0.28)$ & -0.527 \\
\hline Under 15 years & $1.51(0.14)$ & $1.55(0.21)$ & $1.47(0.19)$ & 0.28 \\
\hline $15-59$ years & $4.27(0.18)$ & $4.31(0.26)$ & $4.22(0.25)$ & 0.24 \\
\hline Above 59 years & $0.63(0.08)$ & $0.43(0.09)$ & $0.84(0.13)$ & $-2.57 * *$ \\
\hline Dependency ratio & $0.68(0.07)$ & $0.61(0.08)$ & $0.75(0.11)$ & -0.14 \\
\hline Total male & $3.37(0.15)$ & $3.14(0.20)$ & $3.61(0.23)$ & -1.57 \\
\hline Total female & $3.04(0.15)$ & $3.16(0.25)$ & $2.92(0.16)$ & 0.79 \\
\hline
\end{tabular}

Figures in the parentheses indicate standard error of mean. $* *$ indicates significance at $5 \%$ level.

Gender decision and major involvement of the respondents in production in study area Gender decision in the production of agricultural produce among large holders and small holders was insignificant. However, gender involvement in buying of pesticides was found significant at $10 \%$ level among the large holders and small holders. The involvement of female in buying pesticides was higher in the small holders $(11.8 \%)$ than the large holders $(2.1 \%)$. On the contrary, the major involvement of male in buying pesticides was higher in the large holder $(91.8 \%)$ than the small holders $(74.5 \%)$. And, the major involvement of both male and female was higher in the small holders $(13.7 \%)$ than the large holders $(6.1 \%)$. Gender involvement in application of pesticides in the large holder and small holder was insignificant. In overall, $8 \%$ female, $78 \%$ male, $14 \%$ both male and female were involved in the application of pesticides among the 100 respondents (Table 2).

Table 2: Gender decision and major involvement of the respondents in production in study area

\begin{tabular}{|c|c|c|c|c|}
\hline Descriptives & $\begin{array}{l}\text { Overall } \\
(\mathrm{n}=100) \\
\text { Frequency }(\%)\end{array}$ & $\begin{array}{l}\text { small holder } \\
(\mathrm{n}=51) \\
\text { Frequency }(\%)\end{array}$ & $\begin{array}{l}\text { large holder } \\
(\mathrm{n}=49) \\
\text { Frequency }(\%)\end{array}$ & $\begin{array}{l}\text { Test } \\
\mathrm{X}^{2}\end{array}$ \\
\hline Production of agriculture produce & & & & 3.86 \\
\hline Female & 10 & $8(15.7)$ & $2(4.1)$ & \\
\hline Male & 36 & $18(35.3)$ & $18(36.7)$ & \\
\hline Both & 54 & $25(49)$ & $29(59.2)$ & \\
\hline Buying of pesticides & & & & $4.66 *$ \\
\hline Female & 6 & $6(11.8)$ & $1(2.1)$ & \\
\hline Male & 84 & $38(74.5)$ & $45(91.8)$ & \\
\hline Both & 10 & $7(13.7)$ & $3(6.1)$ & \\
\hline Application of pesticides & & & & 2.45 \\
\hline Female & 8 & $6(11.8)$ & $2(4.1)$ & \\
\hline Male & 78 & $37(72.5)$ & $41(73.7)$ & \\
\hline Both & 14 & $8(15.7)$ & $6(12.2)$ & \\
\hline
\end{tabular}

Figures in the parentheses indicate percentage. * indicate levels of significance at 10 percent 
Journal of Agriculture and Natural Resources (2020) 3(1): 265-281

ISSN: 2661-6270 (Print), ISSN: 2661-6289 (Online)

DOI: https://doi.org/10.3126/janr.v3i1.27180

\section{Access to loan, credit source and extension source in the study area}

Access to loan was higher in the large holders (38.6\%) than small holders (33.4\%). However, the difference was not significant. The different source of credit to the respondent was found significant at $5 \%$ level. Both the small holders and the larger holders had used cooperatives as the main source of credit and it was higher in the large holders $(53.1 \%)$ than the small holders $(35.3 \%)$. Also the different source of extension to the farmer's was significant at $5 \%$ level. Major source of extension used by the farmer's was cooperatives (50\%) in both small holders and large holders. As majority of the farmer's were the members of the cooperatives and it provides loan as well as some of them sold the pesticides and thus cooperatives became the major source of credit and extension source to the farmer's (Table 3).

Table 3: Access to loan, credit source and extension source in the study area

\begin{tabular}{|c|c|c|c|c|}
\hline \multirow[t]{2}{*}{ Descriptives } & Overall $(n=100)$ & $\begin{array}{l}\text { small holder } \\
(\mathrm{n}=51)\end{array}$ & $\begin{array}{l}\text { large holder } \\
(\mathrm{n}=49)\end{array}$ & Test \\
\hline & Frequency (\%) & Frequency (\%) & Frequency $(\%)$ & $\mathrm{X}^{2}$ \\
\hline Access to agri. loan (=Yes) & 36 & $17(33.4)$ & $19(38.6)$ & 0.42 \\
\hline Sources of credit & & & & $10.30 * *$ \\
\hline Bank & 30 & $13(25.5)$ & $17(34.7)$ & \\
\hline Money Lender & 14 & $10(19.6)$ & $4(8.2)$ & \\
\hline Relatives & 9 & $8(15.7)$ & $1(2)$ & \\
\hline Cooperatives & 44 & $18(35.3)$ & $26(53.1)$ & \\
\hline Microfinance Institutions & 3 & $2(3.9)$ & $1(1)$ & \\
\hline Sources of extension service & & & & $9.23 * *$ \\
\hline Government Extension & 28 & $10(19.5)$ & $18(37)$ & \\
\hline Cooperatives & 50 & $24(47.3)$ & $26(52.1)$ & \\
\hline Agrochemical retailers/Agrovet & 18 & $12(24.4)$ & $6(10.9)$ & \\
\hline Others i.e. farmers & 4 & $4(9.8)$ & $0(0)$ & \\
\hline
\end{tabular}

Figures in the parentheses indicate Percentage. $* *$ indicates levels of significance at 5 percent.

\section{Number and type of trainings attained by type of farmers}

The mean number of trainings in vegetable cultivation was found significantly higher in large holder (1.18) as compared to the small holder (0.55) at 5\% level of significance. Similarly, the mean number of trainings in pesticide use and management was significantly higher in large holder $(0.51)$ as compared to the small holder $(0.18)$ at $5 \%$ level of significance (Table $4)$.

Among the 100 respondents, only $30 \%$ have found to take the training in IPM. The training on IPM was significantly higher in large holder (40.8\%) as compared to the Small holder $(19.6 \%)$ farmer at $5 \%$ level of significance (Table 5). Farmers cultivating in large area were facilitated with opportunities like training and subsidy. Training of farmer's regarding the pesticide use and management is essential for reduction of misuse and toxicity of the pesticides (Mattah et al., 2015). Trainings also should be given on IPM which is less dependent of pesticides (Jallow et al., 2017 ; Clausen, 2017). 
Journal of Agriculture and Natural Resources (2020) 3(1): 265-281

ISSN: 2661-6270 (Print), ISSN: 2661-6289 (Online)

DOI: https://doi.org/10.3126/janr.v3i1.27180

Table 4: Number of trainings attained by type of farmers

\begin{tabular}{lllll}
\hline Descriptives & $\begin{array}{l}\text { Overall } \\
(\mathrm{n}=100) \\
\text { Mean }(\mathrm{SE})\end{array}$ & $\begin{array}{l}\text { small holder } \\
(\mathrm{n}=51)\end{array}$ & $\begin{array}{l}\text { large holder } \\
(\mathrm{n}=49)\end{array}$ & Test \\
& $0.86(0.15)$ & $0.55(0.14)$ & $1.18(0.26)$ & T value \\
\hline Vegetable Cultivation & $0.34(0.081)$ & $0.18(0.05)$ & $0.51(0.15)$ & $-2.20^{* *}$ \\
Pesticide use and Management & &
\end{tabular}

Figures in the parentheses indicate standard error of mean. ** indicates levels of significance at 5 percent.

Table 5: Percentage of farmer who take IPM training

\begin{tabular}{llllll}
\hline Descriptive & $\begin{array}{l}\text { Overall } \\
(\mathrm{n}=100) \\
\text { Frequency }(\%)\end{array}$ & $\begin{array}{l}\text { small holder } \\
(\mathrm{n}=51) \\
\text { Frequency }(\%)\end{array}$ & $\begin{array}{l}\text { large holder } \\
(\mathrm{n}=49) \\
\text { Frequency }(\%)\end{array}$ & \multicolumn{2}{l}{ Test } \\
\hline Take IPM (= Yes) & 30 & $10(19.6)$ & $20(40.8)$ & & $5.35^{* *}$ \\
\hline
\end{tabular}

Figures in the parentheses indicate percentage. $* *$ indicate levels of significance at 5 percent

\section{Triggering factors that lead to the use of chemical pesticides}

These chemical pesticides were easily available in the market in different forms and it was easy to use than other organic type of pesticides and gives quick response. Morever, consumers' prefer visually attractive fruits. Majority of the farmer's used Carbendazim 12\% + Mancozeb 63\% (Saaf) before the harvesting of tomato to give lightening effect. Most $(84 \%)$ of the farmer's used the chemical pesticides due to its quick response nature (Figure 2). Similarly, $16 \%$ use due to easyness and preferences of consumer to only visually appealing products. These chemical pesticides were available in different forms viz; wettable powder, emulsifiable concentrate, dust, suspension, etc and thus easy to uses the ready made forms of these pesticides.

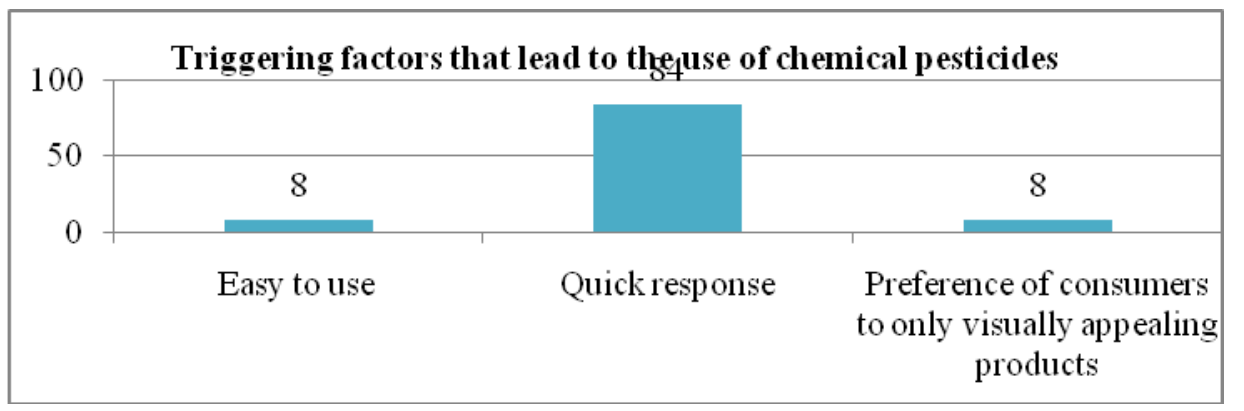

Figures 2: Triggering factors that lead to the use of chemical pesticides

\section{Start to apply chemical pesticides in the vegetables}

Farmer's starts to use the chemical pesticides from 1960's in Nepal. The trend of using pesticides is increasing day by day due to it's quick response and other characteristics. Among the 100 respondents, $66 \%$ of the farmer used the chemical pesticides before $10 \mathrm{yrs}$, $21 \%$ used before $5-10$ years and $13 \%$ used from last 5 years (Figure 3 ). 
Journal of Agriculture and Natural Resources (2020) 3(1): 265-281

ISSN: 2661-6270 (Print), ISSN: 2661-6289 (Online)

DOI: https://doi.org/10.3126/janr.v3i1.27180

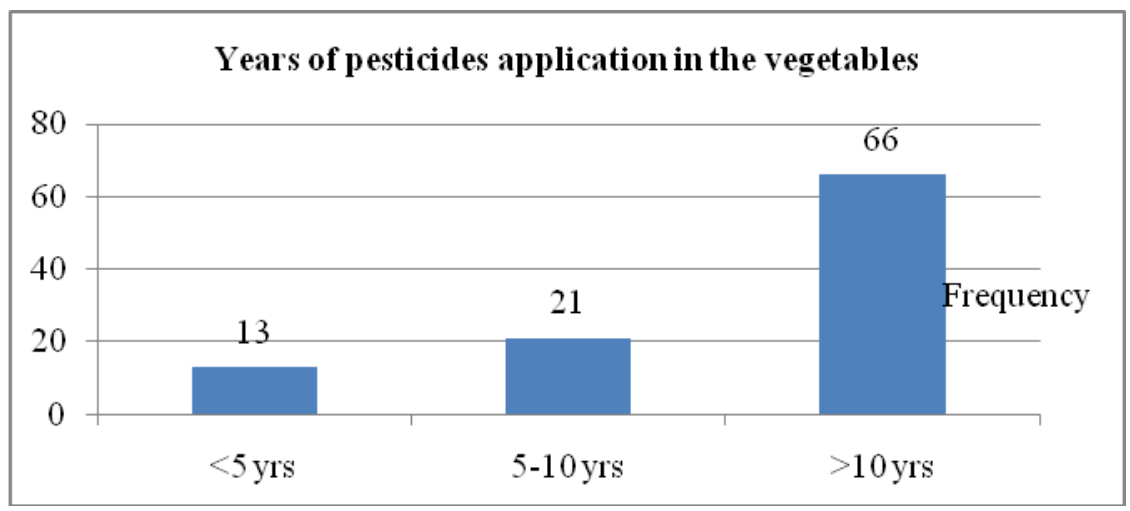

Figures 3: Years of pesticides application in the vegetables

\section{Major damaging forms of pest in study area}

There are different forms of pests that deteriorates the growing vegetables. In the study area, Insects $(51 \%)$ caused the highest damage of vegetable crops which was followed by Disease $(36 \%)$, Weeds (6\%), Rodents (5\%) and others i.e. animals (2\%) respectively (Figure 4). As most used forms of pesticides reported by the farmer's is Insecticides (from table: 16). This pests can damage the vegetables upo $100 \%$.

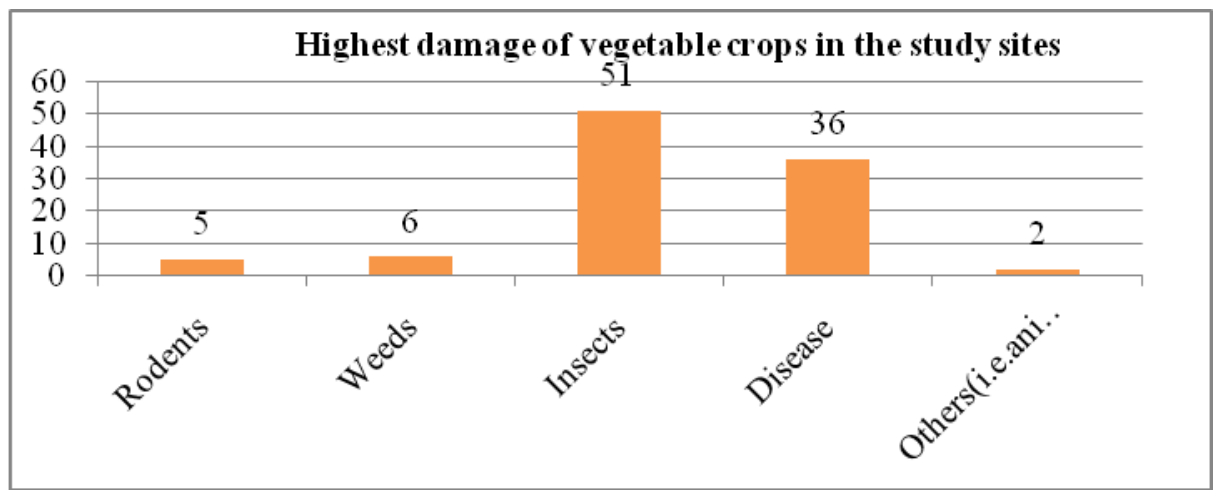

Figure 4: Major damaging forms of pests in the study area

\section{Time for spray of pesticides}

The spray of pesticides in the evening time would be safer as compared to the morning and the day time. Time for spraying of pesticides was significant differences among the large holder and small holder farmer at $10 \%$ level of significance. Among the 100 respondents, $54 \%$ of the farmers spray during the morning time among which small holder was higher $(56.9 \%)$ than large holder $(51.1 \%)$. On the contrary, spraying during evening time, large holder $(46.9 \%)$ was higher as compared to the small holder $(29.4 \%)$ spraying during the time of evening (Table 6). 
Journal of Agriculture and Natural Resources (2020) 3(1): 265-281

ISSN: 2661-6270 (Print), ISSN: 2661-6289 (Online)

DOI: https://doi.org/10.3126/janr.v3i1.27180

Table 6: Time for spray of pesticides by the farmer

\begin{tabular}{|c|c|c|c|c|}
\hline Descriptives & $\begin{array}{l}\text { Overall } \\
(\mathrm{n}=100) \\
\text { Frequency }(\%)\end{array}$ & $\begin{array}{l}\text { small holder } \\
(\mathrm{n}=51) \\
\text { Frequency }(\%)\end{array}$ & $\begin{array}{l}\text { large holder } \\
(\mathrm{n}=49) \\
\text { Frequency }(\%)\end{array}$ & $X^{2}$ \\
\hline At morning & 54 & $29(56.9)$ & $25(51.1)$ & \multirow{4}{*}{$6.52 *$} \\
\hline At early afternoon & 7 & $6(11.8)$ & $1(2)$ & \\
\hline At late afternoon & 38 & $15(29.4)$ & $23(46.9)$ & \\
\hline At evening & 1 & $1(2)$ & $0(0)$ & \\
\hline
\end{tabular}

Notes: Figures in parentheses resemble percentage. * indicates levels of significance at $10 \%$ respectively.

\section{Practiced pattern of waiting period followed by the farmer's}

Waiting period followed by the large holders and small holders farmer have insignificant difference among each other. In overall cases, mean waiting period followed by the majority of the farmer was 3-5 days (Table 7). Lesser the waiting period of the vegetables, higher will be the residual effects in the vegetables and it will directly harms to the health of the vegetable grower's as well as consumer (Koirala et al.,2009). The uses of such types of chemical pesticides causes the imbalance of nature.

Table 7: Practiced pattern of waiting period

\begin{tabular}{lllll}
\hline Descriptives & $\begin{array}{l}\text { Overall } \\
(\mathrm{n}=100)\end{array}$ & $\begin{array}{l}\text { small holder } \\
(\mathrm{n}=51)\end{array}$ & $\begin{array}{l}\text { large holder } \\
(\mathrm{n}=49)\end{array}$ & Test \\
& Frequency $(\%)$ & Frequency $(\%)$ & Frequency $(\%)$ & $\mathrm{X}^{2}$ \\
\hline $1-2$ days & 30 & $15(29.4)$ & $15(30.6)$ & 1.04 \\
$3-5$ days & 56 & $28(54.9)$ & $28(57.1)$ & \\
$7-10$ days & 13 & $7(13.7)$ & $6(12.2)$ & $0(0)$ \\
$>10$ days & 1 & $1(2)$ & & \\
\hline
\end{tabular}

Figures in the parentheses indicate percentage.

\section{Experiences on vegetables needed most pesticides}

Farmer produce cucurbits, Cole crops (cabbage and cauliflower), Solanaceous crops (tomato and brinjal) and Snap bean are the major vegetables growing in Dhading district. Experiences in use of pesticides among different vegetables were significant at 5\% level among large holders and small holders. High amount of pesticides residues was obtained in tomato in comparisons to other different vegetables (Sharma, 2015) which was due to the high frequency and quantity of pesticide used. Farmer's experienced the highest amount of pesticides is needed in tomato and it was higher in small holders $(47.1 \%)$ than large holders (36.7\%) (Table 8).

Table 8: Farmer experience on vegetables needed most pesticides

\begin{tabular}{lllll}
\hline Descriptives & $\begin{array}{l}\text { Overall } \\
(\mathrm{n}=100)\end{array}$ & $\begin{array}{l}\text { small holder } \\
(\mathrm{n}=51)\end{array}$ & $\begin{array}{l}\text { large holder } \\
(\mathrm{n}=49)\end{array}$ & Test \\
& Frequency $(\%)$ & Frequency $(\%)$ & Frequency $(\%)$ & $\mathrm{X}^{2}$ \\
\hline Cucurbits & 21 & $9(17.6)$ & $12(24.5)$ & \\
Cabbage & 5 & $5(9.8)$ & $0(0)$ & $13.08^{* *}$ \\
Cauliflower & 6 & $5(9.8)$ & $1(2)$ & $18(36.7)$ \\
Tomato & 42 & $24(47.1)$ & $17(34.7)$ & \\
Brinjal & 24 & $7(13.7)$ & $1(2)$ & \\
Snap Bean/ Ghiu Simi & 2 & $1(2)$ & & \\
\hline
\end{tabular}

Figure in the parentheses indicate percentage. $* *$ indicates significance at 5 percent level. 
Journal of Agriculture and Natural Resources (2020) 3(1): 265-281

ISSN: 2661-6270 (Print), ISSN: 2661-6289 (Online)

DOI: https://doi.org/10.3126/janr.v3i1.27180

\section{Disposed of pesticide container after use}

Farmer's practiced different methods for the disposal of pesticides. However, the major practiced method followed in overall cases by the farmer was throw in the secret place (43\%) which was higher in small holder $(45.1 \%)$ than large holder (40.8\%). Pesticides containers should through in the secret places to reduce it's health hazards. The disposal of pesticide containers after it's uses contradicts with the case study of Bhaktapurs where $56.1 \%$ thrown in the field and only $2.45 \%$ of the farmer's throw in secret place after it's uses (Budhathoki et al., 2019).

Table 9: Disposal place of pesticide container after use

\begin{tabular}{|c|c|c|c|c|}
\hline Descriptives & $\begin{array}{l}\begin{array}{l}\text { Overall } \\
(\mathrm{n}=100)\end{array} \\
\text { Frequency }(\%)\end{array}$ & $\begin{array}{l}\text { small holder } \\
(\mathrm{n}=51) \\
\text { Frequency }(\%)\end{array}$ & $\begin{array}{l}\text { large holder } \\
(\mathrm{n}=49) \\
\text { Frequency }(\%)\end{array}$ & $\begin{array}{l}\text { Test } \\
\mathrm{X}^{2}\end{array}$ \\
\hline Bury & 15 & $6(11.8)$ & $9(18.4)$ & \\
\hline Burning & 29 & $16(31.4)$ & $13(26.5)$ & \\
\hline Throw in field & 11 & $4(7.8)$ & $7(14.3)$ & 3.9 \\
\hline Throw in secret place & 43 & $23(45.1)$ & $20(40.8)$ & \\
\hline Throw in river & 2 & $2(3.9)$ & $0(0)$ & \\
\hline
\end{tabular}

Figure in the parentheses indicates percentage.

\section{Major health hazards (Symptoms) faced by the farmers}

Different types of health hazards or acute symptoms were reported by the farmers. The major acute symptoms reported with their Frequency were reported in the table 7 . The symptoms of headache was observed in $57 \%$ of the respondents which was significantly higher in small holder $(66.7 \%)$ as compared to large holder $(46.9 \%)$ at $5 \%$ level of significance. The symptoms of headache corresponds with the context of sunsari district i.e.58.8\% (Lamichhane et al., 2019) And, the symptoms of burning sensation was significantly higher in large holder $(67.3 \%)$ as compared to the small holder $(43.1 \%)$ at $5 \%$ level of significance. In overall, headache $(57 \%)$ was observed as major acute symptoms to the farmers (Table 9).

Table 10: Major health hazards (Symptoms) faced by the farmers

\begin{tabular}{|c|c|c|c|c|}
\hline Descriptives & $\begin{array}{l}\text { Overall } \\
(\mathrm{n}=100) \\
\text { Frequency }(\%)\end{array}$ & $\begin{array}{l}\text { Small holder=0 } \\
(\mathrm{n}=51) \\
\text { Frequency }(\%)\end{array}$ & $\begin{array}{l}\text { Large holder=1 } \\
(\mathrm{n}=49) \\
\text { Frequency }(\%)\end{array}$ & $X^{2}$ \\
\hline Vomiting (=yes) & 11 & $5(9.8)$ & $6(12.2)$ & 0.152 \\
\hline Dizziness (=yes) & 45 & $23(45.1)$ & $22(44.9)$ & 0.00 \\
\hline Headache (=yes) & 57 & $34(66.7)$ & $23(46.9)$ & $3.97 * *$ \\
\hline Burning Sensation (=yes) & 55 & $22(43.1)$ & $33(67.3)$ & $5.92 * *$ \\
\hline Skin Irritation (=yes) & 44 & $21(41.2)$ & $23(46.9)$ & 0.33 \\
\hline Teary eyes (=yes) & 56 & $28(54.9)$ & $28(57.1)$ & 0.05 \\
\hline
\end{tabular}

Figures in the parentheses indicate percentage. $* *$ indicate levels of significance at $5 \%$ level.

\section{Uses of Personal Protective Equipment (PPE) / Safety measures}

The use of Personal Protective equipments (PPE) minimizes the effects of pesticide on human health. Otherwise, the pesticides may enter through the different openings of the body and accumulation in the fatty tissues. Use of Mask and Cap/Hat was significantly higher in large holder $(91.8 \%$ and $49 \%)$ as compared to the small holder $(74.7 \%$ and $29.4 \%)$ at $5 \%$ level of significance. And use of rubber boot was significantly higher in large holder $(46.9 \%)$ as compared to the small holder $(21.6 \%)$ at $10 \%$ level of significance. Majority of the 
Journal of Agriculture and Natural Resources (2020) 3(1): 265-281

ISSN: 2661-6270 (Print), ISSN: 2661-6289 (Online)

DOI: https://doi.org/10.3126/janr.v3i1.27180

farmer's didn't use PPE while spraying of pesticides (Mohammad et al., 2018). This study shows that use of PPE was found higher in large holder as compared to small holder and in overall cases and most used type of PPE was Mask (83\%) (Table 10). Majoriry of the farmers are not aware about th safe handling practices of pesticides. Studies shows about more than $50 \%$ of the farmers use their bare hand while spraying of pesticides (Shrestha, 2010).

Table 11: Uses of Personal Protective Equipment (PPE) / Safety measures

\begin{tabular}{lllll}
\hline Descriptives & $\begin{array}{l}\text { Overall } \\
(\mathrm{n}=100)\end{array}$ & $\begin{array}{l}\text { small holder=0 } \\
(\mathrm{n}=51)\end{array}$ & $\begin{array}{l}\text { large holder=1 } \\
(\mathrm{n}=49)\end{array}$ & $\begin{array}{l}\text { Test } \\
\mathrm{X}^{2}\end{array}$ \\
\hline Mask (=yes) & 83 & $38(74.7)$ & $45(91.8)$ & $5.32^{* *}$ \\
Gloves (=yes) & 30 & $13(2.5)$ & $17(34.7)$ & 1.008 \\
Eye protector (=yes) & 17 & $6(11.8)$ & $11(22.4)$ & 2.02 \\
Apron (=yes) & 45 & $22(43.1)$ & $23(46.9)$ & 0.15 \\
Rubber Boots (=yes) & 34 & $11(21.6)$ & $23(46.9)$ & $7.17^{*}$ \\
Cap/Hat (=yes) & 39 & $15(29.4)$ & $24(49)$ & $4.02^{* *}$ \\
\hline
\end{tabular}

Figures in the parentheses indicate percentage. $* *$ and $*$ indicate significance at 5 and 1 percent level respectively.

\section{Spray of pesticides by making it cocktail}

Farmer sprays the pesticides by making single and mixed (cocktail) method. In overall, 59\% of the respondents spray the pesticides by single method (Table 11) which corresponds with the national scenario of $60 \%$ (KC et al., 2014). Similarly, 27\% of the respondents spray in cocktail method sometimes and $14 \%$ of the respondents always spray by making the cocktail. Many farmers has the practices of cocktail application in which they mix different types of dust and liquid pesticides along with micronutrients in the sprayer tank to reduce the time of application (FAO, 2017). On applying the pesticides in cocktail method has synergetic or multiple effects. However, inappropriate mixtures of pesticides increases the pest resistance (Smit et al., 2002).

Table 12: Spraying method of pesticides

\begin{tabular}{|c|c|c|c|c|}
\hline Descriptives & $\begin{array}{l}\text { Overall } \\
(\mathrm{n}=100) \\
\text { Frequency }(\%)\end{array}$ & $\begin{array}{l}\text { small holder }=0 \\
(\mathrm{n}=51) \\
\text { Frequency }(\%)\end{array}$ & $\begin{array}{l}\text { large holder }=1 \\
(\mathrm{n}=49) \\
\text { Frequency }(\%)\end{array}$ & $\begin{array}{l}\text { Test } \\
\mathrm{X}^{2} \\
\end{array}$ \\
\hline No & 59 & $31(60.8)$ & $28(57.1)$ & \multirow{3}{*}{0.45} \\
\hline Yes, Sometimes & 27 & $15(29.4)$ & $12(24.5)$ & \\
\hline Yes, often & 14 & $5(9.8)$ & $9(18.4)$ & \\
\hline
\end{tabular}

Figures in the parentheses indicate percentage.

\section{Way of applying pesticides by the farmers}

In the way of applying the pesticides by the farmer's, large holders was significantly different from small holders at 5\% level of significance. Majority ( $78 \%$ in overall) spray by the instruction of pesticide retailers and it was higher in large holders $(83.7 \%)$ than small holders $(72.5 \%)$. In the randomly application of pesticides, it was higher in small holders $(25.5 \%)$ than large holders $(8.2 \%)$. This shows small holders were less conscious than large holders in the application of pesticides. Only 5\% (in overall) spray the pesticides by the information written in the label. Farmer's were found use next and next pesticides until it completely kills the pest. 
Journal of Agriculture and Natural Resources (2020) 3(1): 265-281

ISSN: 2661-6270 (Print), ISSN: 2661-6289 (Online)

DOI: https://doi.org/10.3126/janr.v3i1.27180

Table 13: Way of applying pesticides by the farmers

\begin{tabular}{|c|c|c|c|c|}
\hline Descriptives & $\begin{array}{l}\begin{array}{l}\text { Overall } \\
(\mathrm{n}=100)\end{array} \\
\text { Frequency }(\%)\end{array}$ & $\begin{array}{l}\begin{array}{l}\text { small holder }=0 \\
(\mathrm{n}=51)\end{array} \\
\text { Frequency }(\%)\end{array}$ & 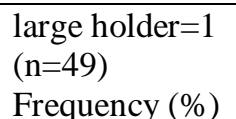 & $\begin{array}{l}\text { Test } \\
\mathrm{X}^{2}\end{array}$ \\
\hline & & & & $6.73^{* *}$ \\
\hline Instruction by pesticide retailer & 78 & $37(72.5)$ & $41(83.7)$ & \\
\hline Written in the label & 5 & $1(2)$ & $4(8.2)$ & \\
\hline Randomly & 17 & $13(25.5)$ & $4(8.2)$ & \\
\hline
\end{tabular}

Notes: Figures in parentheses resemble percentage. ${ }^{* *}$ indicates levels of significance at 5\%

Perception of farmer regarding the change in biological and physical properties of soil after pesticides application

Farmer's perception in change in biological and physical properties of the soil was insignificant among large holders and small holders. Among the 100 respondents, 54\% of the farmer's (in overall) reported change in biological and physical properties of the soil after pesticides application (Table 13). This pesticide not only affects the human health but also kills the soil beneficial micro-organisms (flora and fauna) and pollutes the soil as a whole (Pimentel, 2005).

Table 14: Farmer's perception on change in biological and physical properties of soil after pesticide application.

\begin{tabular}{|c|c|c|c|c|}
\hline Descriptives & $\begin{array}{l}\text { Overall } \\
(\mathrm{n}=100) \\
\text { Frequency }(\%)\end{array}$ & $\begin{array}{l}\text { small holder }=0 \\
(\mathrm{n}=51) \\
\text { Frequency }(\%)\end{array}$ & $\begin{array}{l}\begin{array}{l}\text { large holder }=1 \\
(\mathrm{n}=49)\end{array} \\
\text { Frequency }(\%)\end{array}$ & Test \\
\hline & & & & 1.22 \\
\hline No & 13 & $8(15.7)$ & $5(10.2)$ & \\
\hline Yes & 54 & $25(49)$ & $29(59.2)$ & \\
\hline Didn't notice & 33 & $18(35.3)$ & 15 (30.6) & \\
\hline
\end{tabular}

Figures in the parentheses indicate percentage.

\section{Aware about the negative effects of pesticides}

From the table, it can be understood that $84 \%$ of the respondents were aware about the negative or harmful effects of the pesticides (Table 14). This was accordance with the national situation where majority of the respondents were aware about the impacts of the pesticides (KC et al., 2014). Although they have knowledge on harmful effects, they have done negligence on the safety measures during the storage, handling and application of pesticides. Farmer's were forced to use the chemical pesticides due to the lack of suitable alternatives.

Table 15: Aware about the negative effects of pesticides

\begin{tabular}{lllll}
\hline Descriptives & $\begin{array}{l}\text { Overall } \\
(\mathrm{n}=100)\end{array}$ & $\begin{array}{l}\text { small holder } \\
(\mathrm{n}=51)\end{array}$ & $\begin{array}{l}\text { large holder } \\
(\mathrm{n}=49)\end{array}$ & Test \\
& Frequency $(\%)$ & Frequency $(\%)$ & Frequency $(\%)$ & $\mathrm{X}^{2}$ \\
\hline Aware (=Yes) & 84 & $43(84.3)$ & $41(83.7)$ & 0.008 \\
\hline
\end{tabular}

Figures in the parentheses indicate percentage. 
Journal of Agriculture and Natural Resources (2020) 3(1): 265-281

ISSN: 2661-6270 (Print), ISSN: 2661-6289 (Online)

DOI: https://doi.org/10.3126/janr.v3i1.27180

\section{Ranking of 3 forms of pesticides mostly used by the farmer}

Farmers were asked to rank the first 3 forms of the pesticides in which third form of pesticides were used by only 64 farmers. Three point scaling technique (3,2 and 1) was used to identified the first 3 forms of pesticides used by the farmer. Insecticides was identified as the first major form of pesticides used by the farmer's with an index value of 2.39 as the respondents have reported that the highest damage was caused by the insects. Then after fungicide was identified as the second major pesticides used by the farmer was identified as fungicides with an index value of 2.29 which was also the same case of damaging. And, the third forms of pesticides used by the farmer were identified as Rodenticides with an index value of 0.29 . Similarly fourth, fifth and sixth forms of pesticides used by the farmer was identified as Herbicides, Fumigants and Nematicides with an index value of 0.28, 0.08 and 0.01 respectively (Table 15 ).

Table 16 : Most used forms of pesticides by the farmer

\begin{tabular}{llllll}
\hline Descriptives & 3 & 2 & 1 & Index & Rank \\
\hline Insecticides & 40 & 59 & 1 & 2.39 & I \\
Fungicide & 59 & 41 & 0 & 2.29 & II \\
Nematicides & 0 & 0 & 1 & 0.01 & VI \\
Herbicides & 1 & 0 & 25 & 0.28 & IV \\
Rodenticides & 0 & 0 & 29 & 0.29 & III \\
Fumigants & 0 & 0 & 8 & 0.08 & V \\
\hline
\end{tabular}

\section{Scale/ Weightage Index of trust}

Farmers were asked to rank the major source of trust. Four point scaling technique $(1,0.75$, 0.5 and 0.25 ) was used to identified the major source of trust by the farmer. Agrovet (major pesticide retailers) was identified as first source of trust among the farmer with the index value of 0.83 . Farmers were found to have lack of knowledge on the different types of pesticides and on its uses and other agricultural inputs for which farmer have to completely depend upon the Agrovet. Then after cooperatives was identified as second source of trust with the index value of 0.81 as most of the farmer were in the member's of cooperatives from which they can take loan and make some plan and program at local level. The third and fourth trust was identified as government and local leaders with an index value of 0.30 and 0.068 respectively (Table 16$)$.

Table 17: Scale/ Weight age Index of trust

\begin{tabular}{lllllll}
\hline Trust Source & 1 & 0.75 & 0.5 & 0.25 & Index & Rank \\
\hline Government & 8 & 13 & 74 & 5 & 0.68 & III \\
Agro vet & 40 & 53 & 6 & 1 & 0.83 & I \\
Cooperatives & 49 & 31 & 17 & 2 & 0.81 & II \\
Local leaders & 3 & 3 & 3 & 92 & 0.30 & IV \\
\hline
\end{tabular}

\section{Correlation between Knowledge level of waiting period and practice pattern of waiting} period in vegetable crops

The practice patterns of waiting period of vegetable followed by the farmer's significantly correlates $(r=0.321)$ with their Knowledge of waiting period. For those who respond to the survey, they follow the waiting period practice regarding with their knowledge (Table 17). 
Journal of Agriculture and Natural Resources (2020) 3(1): 265-281

ISSN: 2661-6270 (Print), ISSN: 2661-6289 (Online)

DOI: https://doi.org/10.3126/janr.v3i1.27180

Table 18: Correlation between Knowledge level of waiting period and practice pattern of waiting period

\begin{tabular}{lcc}
\hline Spearman Correlation & r-value & p-value \\
\hline $\begin{array}{l}\text { Waiting period (Knowledge) } \\
\text { Waiting period (Practice) }\end{array}$ & $0.321^{* *}$ & 0.001 \\
\hline Notes: Calculated value of r compared with 'critical value of r'. ** indicate levels of significance at 5\% level.
\end{tabular}

\section{Correlation between Personal Protective Equipment (PPE) score and Health Hazard (HH) score}

PPE score was calculated by adding the total score of each equipment used by the farmer's during the time of spraying and $\mathrm{HH}$ score was calculated by adding the total score of each health related symptoms faced by the farmer after spraying of the pesticides.

PPE score found negatively correlated with HH score and insignificant among each other. This shows using of PPE decreases the HH symptoms (Table 18).

Table 19: Correlation between Personal Protective Equipment (PPE) score and Health Hazard (HH) score

\begin{tabular}{lll}
\hline Spearman Correlation & r-value & p-value \\
\hline PPE score & & \\
HH score & -0.103 & 0.308 \\
\hline
\end{tabular}

Notes: Calculated value of $r$ compared with 'critical value of $r$ '

\section{Read the instructions and knowledge about Label of pesticides}

Label of pesticides indicates the toxicity of pesticides. In the study population, $46 \%$ of the respondents in overall was reported to read or see the instructions and label while buying the pesticides and insignificant among small holders and large holders. Majority of the farmer's were reported to use the pesticides labeled with the yellow colour. Regarding the knowledge of label colour i.e. poisonous or toxicity, it was significantly higher in large holders $(81.6 \%)$ than small holders $(54.9 \%$ ) at $5 \%$ level of significance (Table 19). The knowledge regarding the label of pesticides among farmer's is $68 \%$ which is somehow similar with the condition of Bhaktapur i.e. $63 \%$ of farmer's (Budhathoki et al., 2019).

Table 20: Read the instructions and knowledge about Label of pesticides

\begin{tabular}{lllll}
\hline Descriptives & $\begin{array}{l}\text { Overall } \\
(\mathrm{n}=100)\end{array}$ & $\begin{array}{l}\text { small holder } \\
(\mathrm{n}=51)\end{array}$ & $\begin{array}{l}\text { large holder } \\
(\mathrm{n}=49)\end{array}$ & Test \\
& Frequency $(\%)$ & Frequency $(\%)$ & Frequency $(\%)$ & $\mathrm{X}^{2}$ \\
\hline $\begin{array}{l}\text { Read label while buying pesticides } \\
\text { (=Yes) }\end{array}$ & 46 & $23(45.1)$ & $23(46.9)$ & 0.034 \\
$\begin{array}{l}\text { Color of label indicates } \\
\begin{array}{l}\text { Poisonous } \\
\text { Non- Poisonous }\end{array}\end{array}$ & & & $8.2 * *$ \\
\hline
\end{tabular}

Notes: Figures in parentheses resemble percentage. ${ }^{* *}$ indicates significance at $5 \%$ level.

\section{CONCLUSION}

Farmer's experienced the highest amount of pesticides was use in tomato among different major vegetables. Most used forms of pesticides were insecticides and the major sources of trust to the farmer's were cooperatives. Sixty six percent of the farmer's were found to apply 
Journal of Agriculture and Natural Resources (2020) 3(1): 265-281

ISSN: 2661-6270 (Print), ISSN: 2661-6289 (Online)

DOI: https://doi.org/10.3126/janr.v3i1.27180

the pesticides before 10 yrs. The safety measures used by the farmer's were not satisfactory. Although, mask was common PPE used by the respondents, a large proportion didn't use other protective equipments and overall use of PPE was less in case of small holder farmers. And, headache was the major acute symptoms faced by the farmer's i.e. 57\% of the respondents. Eight four percent of the farmer's were aware about negative effects of pesticides. Although they have knowledge on harmful effects, they have done negligence on the safety measures during the storage, handling and application of pesticides. Promotion of Integrated Pest Management (IPM) is necessary to reduce the consumption of chemical pesticides. Trainings regarding the safe handling, rational use and storage of pesticides should be needed

\section{ACKNOWLEDGEMENTS}

Authors want to thank the Agriculture and Forestry University and Prime Minister Agriculture Modernization Project family for their mentorship.

\section{Author Contributions}

S.B and S.R designed the questionnaire; S.B, S.P (first) and S.P (second) conducted the field survey; S.B and S.R analyzed and interpreted the data; S.B wrote the manuscript; B.P.G reviewed and suggests for manuscript and H.K.M reviewed for final publication.

\section{Conflict of Interests}

Authors declare no conflict of interests.

\section{REFERENCES}

Abhilash, P., \& Singh, N. (2009). Pesticide use and an apllication: An Indian Scenario. Jour of Haz Mat, 165, 1-9.

ADS (2016). Ministry of Agricultural Development, Singha Durbar, Kathmandu, Nepal.

Antonella, F., Bent, I., Manuela, T., Sara, V., \& Macro, M. (2001). Preventing health risk from the use of pesticides in agriculture. Protecting workers health series. Geneva: World Health Organization.

Atreya, K., \& Sitaula, B. (2010). Mancozeb: Growing risk for agricultural communities. Mancozeb: Growing risk for agricultural communities, 6(8).

Atreya, K., Johnsen, F., \& Sitaula, B. (2012). Health and Environment costs of pesticide use in vegetable farming in Nepal. Environment Development and Sustainability.

Budhathoki, N. R., Acharya, P. R., \& Karki, D. (2019). Handling pattern of pesticides in vegetables: A case study of Bhaktapur. Journal of Science and Engineering, 6, 30-39.

Clausen, A. J. (2017). Effect of integrated pest management training on Ugandan small-scale farmers. Environmental Health Insights, pp. 1-10.

Eldridge, B. ( 2008). Pesticide application and safety training for applicators of public health pesticides. California Department of Public Health, Vector-Borne Disease Section, 1616 Capitol Avenue, MS7307, P.O. Box 997377, Sacramento, CA.

FAO. (2017). Field Guide: Pesticide Management. Kathmandu: Food and Agriculture Organization.

http://www.who.int/heli/risks/toxics/chemicals/en/http://www.who.int/heli/risks/toxics/ chemicals/en/. 
Journal of Agriculture and Natural Resources (2020) 3(1): 265-281

ISSN: 2661-6270 (Print), ISSN: 2661-6289 (Online)

DOI: https://doi.org/10.3126/janr.v3i1.27180

Jallow, M., Awadh, D., Albaho, M., Devi, V., \& B.M., T. (2017). Pesticide knowledge and safety practices among farm workers in Kuwait: results of a survey. International Journal of Environmental Research and Public Health, 14(4), 24.

Jasmine, D., Prasad, T., Pant, S., \& Jayana, B. (2008). Study on major pesticides and fertilizers used in Nepal. Scientific World. 6(6), pp. 76- 80.

KC, B., KC, G. K., Palikhe, B. R., \& Shrestha, K. P. (2014). Final Report on Study on National Pesticide Consumption Statistics in Nepal. Kathmandu: Mount Digit Technology (P.) Ltd.

Koirala, P., Dhakal, S., \& Tamrakar, A. (2009). Pesticide application and Food Safety Issue in Nepal. The Jornal of Agriculture and Environment, 10, 111-114.

Krishi Diary. (2019). Banned Pesticides in Nepal. In M. o. Development. Agriculture Information Training Center.

Lamichhane, R., Lama, Nishant., Subedi, S., Singh.S.B, \& Yadav, B.K. (2019, Jan-March). Use of Pesticides and Health Risk among Farmers in Sunsari District, Nepal. Nepal Health Research Council, 17(42), 66-70.

Mattah, M., Precious, I., Mattah, A., \& Futagbi, G. (2015). Pesticide application among farmers in the catchment of Ashaiman irrigation scheme of Ghana: Health implications. Journal of Environmental and Public Health.

Mohammad, S. S., Gholamhossein, A., \& Rohollah, R. (2018). Farmers' Criteria for Pesticide Selection and Use in the pest control process.

Mostafalou, S., \& Abdollahi, M. (2012). Concerns of environmental persistence of pesticides and human chronic diseases. Clinical and Experimental Pharmacology, S5: e002.

NPC (2016). Fourteen Plan. Singh Durbar, Kathmandu, Nepal.

Pimentel, D. (2005). Environmental and economic costs of the application of pesticides primarily in the United States. Environment, Development and Sustainability, 7:229252.

PPD. ( 2012). Annual Progress Report. Hariharbhawan: Plant Protection Directorate.

PRMS. (2012). Pesticide Statistics Booklet (in Nepali Pesticide Registration and Management Section (PRMS). Ministry of Agriculture Development.

Scheaffer, R. L., Mendenhall, W., \& Ott, L. (1987, Dec). Elementary Survey Sampling. Journal Of American Statistical Association, 400, 1185-1186.

Sharma, D. R. (20015). Use of pesticides and its reside on vegetable crops in Nepal. The Journal of Agriculture and Environment, 16, 33-42

Sharma, D., Thapa, R., Manandhar, H., Shrestha, S., \& Pradhan, S. (2012). Use of pesticides in Nepal and impact on health and environment. Journal of Agriculture and environment, 13, 67-74.

Shrestha, A., \& Shrestha, J. (2017). Production, problems and decision making aspects of Maize seed producers in Banke District, Nepal. Azarian Journal of Agriculture, 4(6), $212-216$.

Shrestha, P. K. (2010). Knowledge, practice and use of pesticides among commercial vegetable growers of Dhading district, Nepal. The Journal of Agriculture and Environment, 11, 95-100.

Subedi, S., Ghimire, Y.N., Adhikari, S.P., Devkota, D., Shrestha, J., Poudel, H.K., \& Sapkota, B.K. (2019b). Adoption of certain improved varieties of wheat (Triticum aestivum L.) in seven different provinces of Nepal. Archives of Agriculture and Environmental Science, 4(4) 404-409 
Journal of Agriculture and Natural Resources (2020) 3(1): 265-281

ISSN: 2661-6270 (Print), ISSN: 2661-6289 (Online)

DOI: https://doi.org/10.3126/janr.v3i1.27180

Subedi, S., Ghimire, Y.N., Gautam, S., Poudel, H.K., \& Shrestha, J. (2019a). Economics of potato (Solanum tuberosum L.) production in terai region of Nepal. Archives of Agriculture and Environmental Science, 4(1), 57-62

WHO (2003). Pesticide residue in food. In: International program on chemical safety Joint FAO/WHO meeting on pesticides results evaluations 2002, part 2 Toxicology.

WHO. (2012). Health and Environment Linkage Initiative, WHO. Toxic hazards.[Internet] 2012 [cited on 2012 April 26]. Available from:

Yassin, M. M., Mourad Abu T.A, \& Safi, J.M., (2002). Knowledge, attitude, practice, and toxicity symptoms associated with pesticide use among farm workers in the Gaza Strip. J. Occup. Environ. Med., 59, 387-394. 